\title{
Secretory antibody response of the cervix to infection with Neisseria gonorrhoeae
}

\author{
A. McMillan,* G. McNeillage,† H. YOUNG, $\neq$ AND S. S. R. BAin§ \\ From the *Department of Sexually Transmitted Diseases, Black Street, Glasgow; the +Department of \\ Venereology, Royal Infirmary, Edinburgh; the $¥$ Department of Bacteriology, University of Edinburgh; \\ and the §Royal Infirmary, Edinburgh
}

SUMMARY Cervical secretions from 157 women were examined for antibody against Neisseria gonorrhoeae by an indirect immunofluorescent antibody test. Antigonococcal antibody was detected in $73(97 \%)$ of 75 infected women, being of the IgG class in $73(97 \%)$, of the IgA class in $71(95 \%)$, and of the IgM class in $29(39 \%)$. IgM antibody was nearly always associated with infections of less than 15 days' duration. Immunoglobulin $G$, reactive with $N$. gonorrhoeae, was found in $23(33 \%)$ of 70 non-infected women; of these, 19 had non-gonococcal cervicitis. Neither IgA nor IgM antibodies were detected in these women. Antigonococcal IgA and IgG was found in each of 12 women who had no evidence of infection but were contacts of infected men. Successful treatment resulted in a rapid decline in IgA antibody activity but a more gradual decrease in IgG reactivity.

\section{Introduction}

Although there has been considerable interest recently in the local immune system of the female reproductive tract there have been few reports relating to infection with Neisseria gonorrhoeae (Tapchaisri and Sirisinha, 1976; Tramont, 1977). Antibody-containing plasma cells are found principally in the lamina propria of the endocervix, there being relatively few cells in the endometrium or uterine tubes (Rebello et al., 1975). Immunoglobulin $\mathrm{A}$ is the predominant antibody class elaborated by these cells, whose numbers in the endocervix have been shown to increase during infection (Chipperfield and Evans, 1972).

Quantitatively, IgG is the principal immunoglobulin detectable in the cervical secretions (Tjokronegoro and Sirisinha, 1975), the ratio of the concentration of IgG to that of secretory $\operatorname{IgA}$ being about 2:1. Ogra and Ogra (1973) demonstrated, however, that the antibody response of the lower reproductive tract to topically applied inactivated poliovirus was associated with $\operatorname{IgA}$, and most studies of the immune response of the genital tract to infection have mainly concerned this class of

Address for reprints: Dr A. McMillan, Department of Venereology, 67 Black Street, Glasgow G4 0EF

Received for publication 30 November 1978 antibody (Waldman et al., 1971: Ackers et al., 1975: O'Reilly et al., 1976).

This paper reports our findings on the local immune response to infection with $N$. gonorrhoeae.

\section{Materials and methods}

\section{PATIENTS AND DIAGNOSTIC TECHNIQUES}

One hundred and fifty seven women were investigated; 92 attended the Department of Sexually Transmitted Diseases at the Black Street clinic, Glasgow, and 65 attended the Department of Venereology at the Royal Infirmary, Edinburgh.

At both centres a Gram-stained smear of material from the urethra and cervix was examined, and culture specimens were taken from these sites and from the anorectum and oropharynx. Infection was excluded only if three sets of culture specimens taken at weekly intervals from these sites gave negative results.

Material for culture from patients attending the Glasgow clinic was taken on charcoal-impregnated swabs and transported to the laboratory in Stuart's transport medium. The culture medium used was Columbia blood agar (Oxoid) containing vancomycin $(2.5 \mu \mathrm{g}$ per $\mathrm{ml})$, trimethoprim $(3.0 \mu \mathrm{g}$ per $\mathrm{ml})$, and polymyxin (15 units per $\mathrm{ml})$. The mean interval between specimen collection and inoculation on the culture medium was nine hours (range 4-16 hours). 
In the Edinburgh clinic, modified New York City (MNYC) medium (Young, 1978) was inoculated directly and held at $36^{\circ} \mathrm{C}$ until transfer to the laboratory (mean time interval $2 \cdot 1$ hours, range 30 minutes to 3 hours).

At both centres the identity of suspected colonies of $N$. gonorrhoeae was confirmed by the oxidase reaction, sugar utilisation tests, and direct immunofluorescence.

Patients were divided into three groups.

\section{Group 1}

This consisted of 75 women from whom $N$. gonorrhoeae was cultured from at least one site. The mean age of this group was 23.4 years, and the mean number of sexual partners within the preceding three months was $1 \cdot 6$. Eight women had previously been infected with $N$. gonorrhoeae, the mean interval between the presenting and most recent infection being 2.7 years (range three months to six years). As a contraceptive method, 58 used an oral oestrogenprogestogen preparation, three had an intrauterine device fitted, and 14 took no contraceptive precautions.

At the time of the initial visit 39 women were in the first half of the menstrual cycle and 36 in the second half.

Two women had acute Bartholinitis and three acute salpingitis. Patients with uncomplicated gonorrhoea were treated in Glasgow with minocycline in a single dose of $300 \mathrm{mg}$, and in Edinburgh with ampicillin $(2 \mathrm{~g})$ and probenecid (1 $\mathrm{g})$ given orally as a singe dose. Complicated infection was treated with doxycycline given orally in a dosage of $100 \mathrm{mg}$ every eight hours for 14 days.

Efficacy of treatment was assessed by microbiological examination of material obtained from the urethra, cervix, rectum, and, if indicated, oropharynx. Cure was assumed only if three sets of tests performed at weekly intervals gave negative results.

No treatment failures were observed during the period of the study.

\section{Group 2}

Seventy women (34 in Glasgow and 36 in Edinburgh) who had no evidence of gonorrhoea were studied. These women were not known sexual contacts of infected men, had no past history of infection, and had not received antimicrobial therapy within the preceding three months.

The mean age of this group was $23 \cdot 6$ years and the mean number of sexual partners within the preceding three months was $1 \cdot 8$. Fifty-two used oral contraception, two had been fitted with an intra- uterine device, and 16 took no contraceptive precautions.

Thirty-seven women were in the first half of the menstrual cycle at their initial visit and 33 in the second half of the cycle.

Twenty-two women had clinical evidence of cervicitis; the cervix was congested and tender on palpation, and there was a marked purulent or mucopurulent discharge from the os.

\section{Group 3}

Twelve women attended (seven in Glasgow and five in Edinburgh) as named sexual contacts of men with culturally proved urethral gonorrhoea. There was, however, no evidence of gonococcal infection. These women had not received antimicrobial treatment within the preceding three months.

\section{COLLECTION OF SPECIMENS}

Cervical secretions were obtained by gentle aspiration through a sterile polythene capillary tube (chromatography column tubing, internal diameter $1.0 \mathrm{~mm}$, obtained from Pharmacia Fine Chemicals, Uppsala, Sweden) attached to a 5-ml syringe containing $1 \mathrm{ml}$ of sterile physiological saline. Secretions in the tubing were ejected into a sterile container and a drop of $0.1 \%$ sodium azide in saline added. Specimens obviously contaminated with blood or giving a positive reaction with Haemastix strips (Ames Co. Ltd, Slough, Bucks) were discarded. The diluted secretions were centrifuged at $400 \times g$ for 20 minutes, and the supernatant stored at $-20^{\circ} \mathrm{C}$ until required.

Cervical secretions were obtained from each patient at the initial clinic visit and, in the case of those infected with gonorrhoea, at seven, 14, and 28 days following treatment. In addition to the initial specimen, secretions from non-infected patients were again sampled 14 days later.

Serum from each patient was obtained at the same time as the cervical secretions.

QUANTITATION OF SECRETORY IgA AND IgG The concentrations of these immunoglobulins were estimated by radial immunodiffusion using commercially available low-level plates (Hoescht Pharmaceuticals, Hounslow, Middlesex). A secretory IgA standard, prepared from colostrum (Samson et al., 1973) and kindly provided by $\mathrm{Dr}$ Brian McClelland (Blood Transfusion Service, Royal Infirmary, Edinburgh) was used in estimating IgA, and a serum IgG standard was used in the determination of IgG.

GONOCOCCAL ANTIGENS

Strain 9 of $N$. gonorrhoeae as described by O'Reilly 
et al. (1973), and kindly supplied by Dr D. S. Kellogg (Center for Disease Control, Atlanta, Georgia, USA) and cultured on MNYC medium was used as gonococcal antigen. In addition, secretions from eight women with gonorrhoea were tested against the homologous strain of the organism.

To test the specificity of the antibody reactivity, secretions were tested against Neisseria meningitidis, Neisseria perflava, Neisseria catarrhalis, Neisseria lactamica, Staphylococcus aureus, Staphylococcus albus, Streptococcus faecalis, and Escherichia coli, cultures of these organisms being obtained from the stock collection of cultures at the Department of Bacteriology at the University of Edinburgh Medical School.

\section{INDIRECT IMMUNOFLUORESCENT ANTIBODY TEST}

The performance of the IFA test has previously been described (McMillan et al., 1979). Doubling dilutions of secretions were tested against strain 9 of $N$. gonorrhoeae.

The system of grading fluorescence described by Welch and O'Reily (1973) was used: 4 + indicates brilliant fluorescence of all organisms; $3+$, welldefined fluorescence of all organisms in the field; $2+$, low density fluorescence of at least $75 \%$ of organisms: and + , occasional fluorescing organisms.

For the purpose of this study 'undiluted secretions' refers to the supernatant fluid obtained after centrifugation of the suspension of cervical aspirate in saline. The titre was taken as the reciprocal of the highest dilution giving a $2+$ result.

\section{ADSORPTION OF SECRETIONS WITH RABBIT \\ ANTI-HUMAN SECRETORY COMPONENT}

Secretions were adsorbed with serum from a rabbit immunised against human secretory component (Hoescht Pharmaceuticals, UK) or with normal rabbit serum, as described by O'Reily et al. (1976).

\section{Results}

IMMUNOGLOBULIN CONCENTRATIONS

The concentrations of total secretory IgA and IgG in the undiluted secretions are shown in Table 1. There was considerable variation in the concentration of each immunoglobulin from patient to patient, but there was no significant difference between the mean concentrations of each group of patients.

\section{IMMUNOGLOBULIN CLASSES OF ANTIBODY \\ REACTIVE WITH N. GONORRHOEAE \\ Untreated infected patients}

The results obtained in the IFA test, using strain 9 of $N$. gonorrhoeae as antigen, are shown in the Figure.
Table 1 Concentrations of secretory $\operatorname{IgA}$ and $\mathrm{IgG}$ in the secretions aspirated from the cervix of women with untreated and treated gonorrhoea, with non-gonococcal cervicitis, and with no clinical evidence of cervicitis

\begin{tabular}{|c|c|c|c|}
\hline \multirow[b]{3}{*}{ Category of patient } & \multirow{3}{*}{$\begin{array}{l}\text { No. of } \\
\text { patients }\end{array}$} & \multicolumn{2}{|c|}{$\begin{array}{l}\text { Concentration of } \\
\text { immunoglobulin }(\mathrm{mg} / \mathrm{dl})\end{array}$} \\
\hline & & $\operatorname{IgA}$ & $\operatorname{Ig} G$ \\
\hline & & Mean Range & Mean Range \\
\hline \multirow{7}{*}{$\begin{array}{l}\text { Gonorrhoea } \\
\text { Untreated } \\
7 \text { days after treatment } \\
14 \text { days after treatment } \\
28 \text { days after treatment } \\
\text { Non-gonococcal cervicitis } \\
\text { No clinical evidence of } \\
\text { cervicitis }\end{array}$} & & & \\
\hline & 28 & $2 \cdot 41 \cdot 1-4 \cdot 8$ & $2 \cdot 01 \cdot 0-3 \cdot 6$ \\
\hline & 29 & $2 \cdot 01 \cdot 1-3 \cdot 7$ & $2 \cdot 31 \cdot 0-4 \cdot 1$ \\
\hline & 30 & $2 \cdot 3 \quad 1 \cdot 0-3 \cdot 8$ & $2 \cdot 31 \cdot 0-3 \cdot 9$ \\
\hline & 28 & $2 \cdot 2 \quad 1 \cdot 0-3 \cdot 8$ & $2 \cdot 5 \quad 1 \cdot 3-3 \cdot 9$ \\
\hline & 19 & $2 \cdot 3 \quad 1 \cdot 2-4 \cdot 4$ & $2 \cdot 21 \cdot 1-4 \cdot 0$ \\
\hline & 29 & $2 \cdot 0 \quad 1 \cdot 0-4 \cdot 1$ & $1 \cdot 8 \cdot 1 \cdot 2-3 \cdot 7$ \\
\hline
\end{tabular}

Antibody reactive with $N$. gonorrhoeae was detected in the cervical secretions of $73(\mathbf{9 7 \%})$ of 75 women with gonorrhoea. In $71(95 \%)$ of these patients the antibody was of the IgA class.

Cervical secretions from 10 women with untreated gonorrhoea were absorbed with anti-human secretory component. In each case, this resulted in a threefold, or greater, reduction in titre of $\operatorname{IgA}$ antibody activity as detected in the immunofluorescent test.

Antigonococcal IgM was found in $29(39 \%)$ of the 75 infected women. This antibody was detected in the cervical secretions of $27 \%(59 \%)$ of the 46 women who had been infected for 14 days or less, but in only two (7\%) of 29 who had been infected longer. This difference is statistically significant $(\mathrm{P}<0.05$ by the method of binomial probabilities).

Immunoglobulin $\mathrm{G}$ reactive with $N$. gonorrhoeae was detected in $73(\mathbf{9 7 \%})$ infected women, being the only class of antigonococcal antibody found in two patients.

In addition to examining the secretions using strain 9 as antigen, specimens from eight infected women, attending consecutively, were tested against the infecting strain of the organism. No difference in immunoglobulin class or in antibody titre was observed in the IFA test between secretions tested against strain 9 and those tested against the infecting strain.

There was no qualitative difference in the antibodies detected in the secretions between women who had previously been infected and those who had not, but the small number of patients precluded a quantitative comparison.

Of the three women with acute salpingitis and the two with Bartholinitis, antibody of the IgA and IgG classes reactive with the gonococcus (strain 9 and homologous strain) was detected in the cervical secretions of each patient, but no antigonococcal IgM was detectable. 


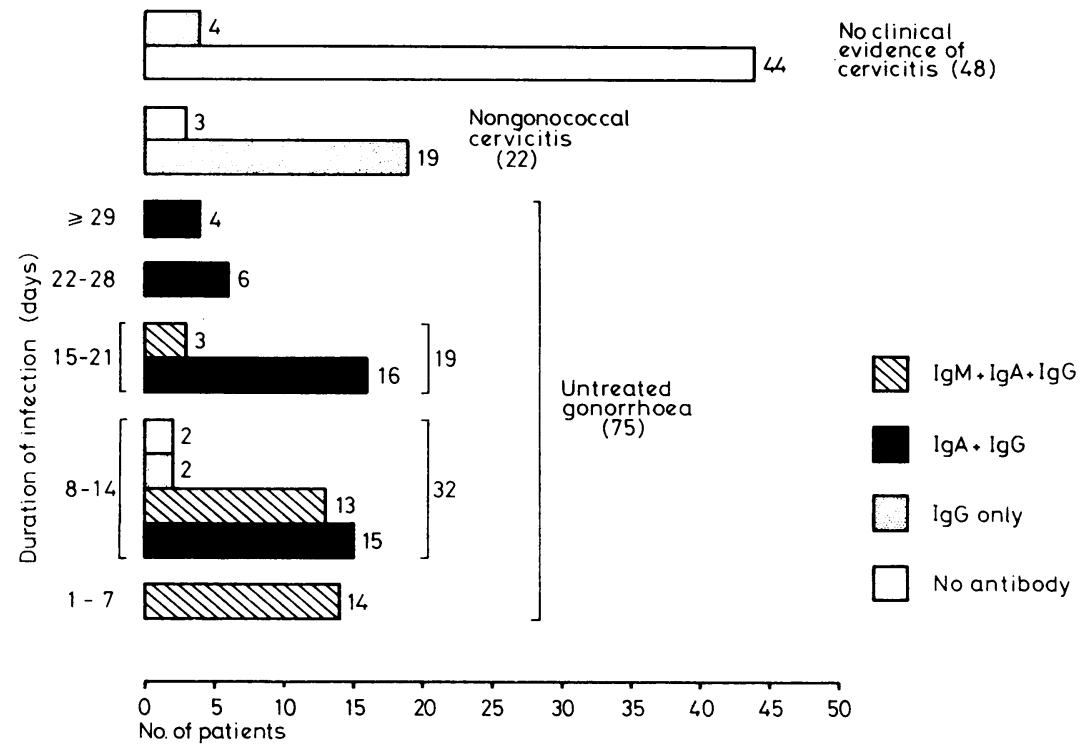

Figure Immunoglobulin classes of antibody reactive with $\mathrm{N}$. gonorrhoeae in cervical secretions.

\section{Non-infected women}

Antibody of the IgG glass reactive with the gonococcus was demonstrated at a titre of $1 / 2$ or less in the secretions of $19(86 \%)$ of 22 women with nongonococcal cervicitis, but in only four $(8 \%)$ of 48 who had no clinical evidence of cervicitis. Antigonococcal antibody of the IgM or IgA class was not detected in the secretions of this group of women.

\section{Treated patients}

The rapid decline in the mean log titre of antigonococcal $\operatorname{IgA}$ following successful treatment is shown in Table 2 . The mean $\log$ titre of $\operatorname{IgG}$ antibody declined more gradually.

Within seven days of successful treatment, antigonococcal IgM could not be detected in the cervical secretions of any of the 54 women who

Table 2 Mean log titre of antibody reactive with $\mathrm{N}$. gonorrhoeae in the cervical secretions before and after successful treatment

\begin{tabular}{|c|c|c|c|}
\hline & \multirow{2}{*}{$\begin{array}{l}\text { No. of } \\
\text { patients }\end{array}$} & \multicolumn{2}{|c|}{$\begin{array}{l}\text { Mean log titre of anti- } \\
\text { gonococcal antibody }\end{array}$} \\
\hline & & $\operatorname{Ig} A$ & $\operatorname{Ig} G$ \\
\hline $\begin{array}{l}\text { Before treatment } \\
7 \text { days after treatment } \\
14 \text { days after treatment } \\
28 \text { days after treatment }\end{array}$ & $\begin{array}{l}75 \\
54 \\
47 \\
43\end{array}$ & $\begin{array}{l}0 \cdot 682 \\
0 \cdot 273 \\
0 \cdot 064 \\
0 \cdot 000\end{array}$ & $\begin{array}{l}0 \cdot 727 \\
0 \cdot 368 \\
0 \cdot 231 \\
0 \cdot 252\end{array}$ \\
\hline
\end{tabular}

attended at this time. This antibody had been detected in 26 of these patients.

Named sexual contacts not found to be infected Antibody of the IgA and IgG classes reactive with $N$. gonorrhoeae was detectable in the cervical secretions of each of the 12 patients studied. This antibody was again found when the IFA test was repeated on secretions obtained on two further occasions within the following three weeks. No antigonococcal IgM was found in the cervical secretions of these women.

\section{SPECIFICITY OF ANTIBODIES AGAINST \\ N. GONORRHOEAE}

The results obtained when cervical secretions from five infected women were examined for antibody against other species of Neisseria are given in Table 3. No antibody against these organisms was detectable in the secretions from six non-infected women using monospecific anti-human IgA.

Antibody of the IgG class reactive with $N$. meningitidis group B was found in the secretions of two non-infected women, of group C in two, of group D in one, of group $\mathrm{E}$ in two, of group $\mathrm{X}$ in one, and of group $\mathrm{Z}$ in three. This antibody of this class was also found against $N$. lactamica in five of six of these women, against $N$. catarrhalis in each of the six, and against $N$. perflava in four.

Antibody against Staph. aureus, Staph. albus, Strep. faecalis, and E. coli was not detectable in the secretions from these infected and non-infected women. 
Table 3 Antibody against Neisseria species in the cervical secretions of five women infected with $\mathrm{N}$. gonorrhoeae

\begin{tabular}{|c|c|c|c|c|c|c|c|c|c|c|}
\hline \multirow[b]{3}{*}{ Species of Neisseria } & \multicolumn{10}{|c|}{ Results of IFA test* } \\
\hline & \multicolumn{2}{|c|}{ Case I } & \multicolumn{2}{|c|}{ Case 2} & \multicolumn{2}{|c|}{ Case 3} & \multicolumn{2}{|c|}{ Case 4} & \multicolumn{2}{|c|}{ Case 5} \\
\hline & $\operatorname{Ig} A$ & $I g G$ & $\operatorname{Ig} A$ & $I g G$ & $\operatorname{Ig} A$ & $\operatorname{Ig} G$ & $\operatorname{Ig} A$ & $I g G$ & $\operatorname{Ig} A$ & $\operatorname{IgC}$ \\
\hline $\begin{array}{l}N . \text { gonorrhoeae } \\
N . \text { meningitidis }\end{array}$ & $4+$ & $3+$ & $4+$ & + & $3+$ & $3+$ & $4+$ & + & $3+$ & $3+$ \\
\hline Group A & - & - & - & - & - & - & - & - & - & - \\
\hline Group B & - & - & - & - & - & $2+$ & - & - & - & $2+$ \\
\hline Group C & - & - & - & - & - & - & - & - & - & - \\
\hline Group D & - & - & - & - & - & $2+$ & - & - & - & - \\
\hline Group E & - & $2+$ & - & - & $2+$ & $2+$ & - & $2+$ & - & - \\
\hline Group $29 \mathrm{E}$ & - & - & - & - & - & - & - & - & - & - \\
\hline Group W135 & - & $2+$ & - & - & 一 & - & - & - & 一 & - \\
\hline Group Y & + & - & - & - & - & - & - & - & - & - \\
\hline Group Z & $2+$ & - & - & - & - & $2+$ & - & - & - & + \\
\hline N. catarrhalis & - & $2+$ & - & - & - & - & - & $2+$ & - & - \\
\hline N. lactamica & $2+$ & $2+$ & - & $2+$ & - & $2+$ & $2+$ & $2+$ & - & $2+$ \\
\hline N. perflava & - & - & - & - & - & - & - & - & - & - \\
\hline
\end{tabular}

*Fluorescence graded as follows: $4+=$ brilliant fluorescence of all organisms in a microscopic field; $3+=$ well defined fluorescence; $2+=$ low intensity fluorescence of all organisms; $+=$ occasional fluorescing organisms; $-=$ no fluorescence.

\section{Discussion}

In this study antigonococcal antibody was detected in the cervical secretions of $97 \%$ of women with untreated gonorrhoea.

Antigonococcal antibody reactivity was associated with both IgG and IgA regardless of the duration of the infection. IgM antibody was, however, detectable mainly during the first two weeks of infections, thereby resembling the serum antibody response previously reported (McMillan et al., 1979). It is difficult to determine whether this class of antibody is derived from serum or is locally produced; certainly IgM-containing plasma cells may be found in the endocervix (Chipperfield and Evans, 1972).

Tapchaisri and Sirisinha (1976), using strain F62T1 of $N$. gonorrhoeae as antigen, found antibody in the secretions of about $60 \%$ of infected women. They further demonstrated that almost all antibody activity was associated with IgG, antigonococcal IgA and IgM being found in only $10 \%$ and $5 \%$ of patients respectively.

The increased sensitivity noted in the present study may reflect the choice of antigen in the IFA test. Strain 9 of $N$. gonorrhoeae has been shown to share antıgenic features with other strains of the organism (O'Reilly et al., 1973).

The threefold or greater reduction in titre of antigonococcal IgA after absorption with antihuman secretory component suggests that most of this antibody is locally produced.

Although antibody of the IgA or IgM classes reactive with $N$. gonorrhoeae was not detected in the cervical secretions of women who had no evidence of gonorrhoea, and who were not known contacts of infected men, antigonococcal IgG was found at a low titre in just under $40 \%(26 / 70)$ of these patients. In
$86 \%$ of patients with clinical evidence of cervicitis, this antibody was detectable and was probably derived from transudation of natural serum IgG through inflamed mucous membranes. Similar findings were recorded by Tapchaisri and Sirisinha (1976).

Tramont (1977) found IgA reactive with strain 9 of the gonococcus in one of two women who had acute pelvic inflammatory disease but no specific IgA antibody against the infecting strain. Antibody of the IgA. class against strain 9 was detected in each of three women in the present study who had acute gonococcal salpingitis. It is difficult to be certain that $N$. gonorrhoeae was the aetiological agent in these women, as other organisms such as Chlamydia trachomatis may be present concomitantly (Mårdh et al., 1977).

The rapid decline in $\operatorname{IgA}$ antibody activity in the secretions following sucessful treatment of gonorrhoea had previously been observed in a smaller series of patients by O'Reilly et al. (1976). Antigonococcal IgG persisted in the secretions of most patients for at least one month after treatment, resembling the serum IgG response (McMillan et al., 1979).

It was of considerable interest to note that antigonococcal antibody could be detected in the secretions of 12 women who were known sexual contacts of infected men but from whom $N$. gonorrhoeae could not be isolated. There was no history of antimicrobial therapy within the preceding three months, and none of the patients was in an occupation with ready access to such drugs. It is possible that these patients had been infected, but their intrinsic immunity had prevented colonisation by the organism. It is well recognised that only a proportion, up to about $70 \%$, of female sexual 
contacts of men with urethral gonorrhoea will be found to be infected (Wallin, 1974).

This project was supported by a grant from the Biomedical Research Committee of the Scottish Home and Health Department (Grant No. $\mathrm{K} / \mathrm{MRS} / 36 / \mathrm{C} 38$ ) whose financial assistance is gratefully acknowledged.

\section{References}

Ackers, J. P., Lumsden, W. H. R., Catterall, R. D., and Coyle, R. (1975). Antitrichomonal antibody in the vaginal secretions of women infected with Trichomonas vaginalis. British Journal of Venereal Diseases, 51, 319-323.

Chipperfield, E. J., and Evans, B. A. (1972). The influence of local infection on immunoglobulin formation in the human endocervix. Clinical and Experimental Immunology, 11, 219-223.

McMillan, A., McNeillage, G., Young, H., and Bain, S. R. (1979) Serum immunoglobulin response in uncomplicated gonorrhoea. British Journal of Venereal Diseases, 55, 5-9.

Mårdh, P.-A., Ripa, K. T., Wang, S.-R., and Westrom, M. L. (1977). Chlamydia trachomatis as an etiological agent in acute salpingitis. In Non-gonococcal Urethritis and Related Infections, p. 77-83. Edited by D. Hobson and K. Holmes, American Society for Microbiology: Washington DC.

Ogra, P. L., and Ogra, S. S. (1973). Local antibody response to polio vaccine in the human female genital tract. Journal of Immunology, 110, 1307-1311.
O'Reilly, R. J., Lee, L., and Welch, B. G. (1976). Secretory IgA antibody responses to Neisseria gonorrhoeae in the genital secretions of infected females. Journal of Infectious Diseases, 133, 113-125.

O'Reilly, R. J., Weich, B. G., and Kellogg, D. S. (1973). An indirect fluorescent-antibody technique for study of uncomplicated gonorrhoea. II Selection and characterisation of the strain of Neisseria gonorrhoeae used as antigen. Journal of Infectious Diseases, 127, 77-83.

Rebello, R., Green, F. H. Y. and Fox, H. (1975). A study of the secretory immune system of the female genital tract. British Journal of Obstetrics and Gynaecology 82, 812-816.

Samson, R. R., McLelland, D. B. L., and Shearman, D. J. C. (1973). Studies on the quantitation of immunoglobulin in human intestinal secretions. Gut, 14, 616-626.

Tapchaisri, C., and Sirisinha, S. (1976). Serum and secretory antibody responses to Neisseria gonorrhoeae in patients with gonococcal infections. British Journal of Venereal Diseases, 52 , 374-380.

Tjokronegoro, A., and Sirisinha, S. (1975) Quantitative analysis of immunoglobulins and albumin in secretion of female reproductive tract. Fertility and Sterility, 26, 413-417

Tramont, E. C. (1977). Inhibition of adherence of Neisseria gonorrhoeae by human genital secretions. Journal of Clinical Investigation, 59, 117-124.

Waldman, R. H., Cruz, J. M., and Rowe, D. S. (1971). Immunoglobulin levels and antibody to Candida albicans in human cervico-vaginal secretions. Clinical and Experimental Immunology, 9, 427-434.

Wallin, J. (1974). Gonorrhoea in 1972. A 1-year study of patients attending the VD unit in Uppsala. British Journal of Venereal Diseases, 51, 41-47.

Welch, B. G., and O'Reilly, R. J. (1973). An indirect fluorescentantibody technique for the study of uncomplicated gonorrhoea. I Methodology. Journal of Infectious Diseases, 127, 69-76.

Young, H. (1978). Cultural diagnosis of gonorrhoea with modified New York City (MNYC) medium. British Journal of Venereal Diseases, 54, 36-40. 